\title{
Petroleum geochemistry of the deepened Lopra-1/1 A re-entry well, Faroe Islands
}

\author{
Jørgen A. Bojesen-Koefoed and H. Peter Nytoft
}

The Lopra-1/1A re-entry well was drilled as a stratigraphic test with no immediate exploration objectives. Hence, petroleum geochemical studies were of limited extent, and restricted to non-destructive analyses. The presence of natural petroleum hydrocarbons could not be confirmed with certainty, but hydrocarbons extracted from the hydrochloric acid solute of a calcite vug present in RSWC \#1 (3543 $\mathrm{m}$ ), may represent indigenous petroleum since hydrocarbon-bearing fluid inclusions have been reported from the same sample. These hydrocarbons show some similarities to petroleum generated from the Upper Jurassic - Lower Cretaceous Kimmeridge Clay type source rocks present in surrounding areas. Except for this sample, the results generally show the presence of a variety of contaminants of different origins such as 'naturally greasy fingers' (squalene and cholesterol), cosmetics such as chap stick or hand lotion (e.g. esters such as butyl-stearate, stearyl-palmitate, vitamin A), plasticisers (phthalates), diesel oil and 'pipe dope'.

Keywords: oil traces, organic geochemistry, contamination, Faroes, North Atlantic, Lopra

Geological Survey of Denmark and Greenland, Øster Voldgade 10, DK-1350 Copenhagen K, Denmark. E-mail: jbk@geus.dk

As part of the preparatory activities prior to an expected future licensing round on Faroese territory, a consortium of oil companies (see Heinesen et al. 2006, this volume) undertook to drill the Lopra-1/1A re-entry well as a stratigraphic test. The primary objectives of the well were to obtain lithological and stratigraphic information on the deepest parts of the Faroese flood basalt sequence as well as its substratum, and to acquire information related to the assessment of the petroleum exploration prospectivity of the area.

The original Lopra-1 well was drilled in 1981 and reached a total depth (TD) of $2178 \mathrm{~m}$. The well penetrated a succession of flood basalts with minor tuffs and two dolerites (probably dykes). The drilled sequence was interpreted as part of the Faroese lower basalt formation or series (Waagstein et al. 1984; Waagstein 1988). The Lopra-1 well was re-entered in 1996 and deepened to a TD of $3565 \mathrm{~m}$. The new drilling showed that the subaerial flood basalt sequence was underlain by a subaqueous hyaloclastite-basalt succession, comprising the interval $2550-3565 \mathrm{~m}$ and consisting predominantly of lapilli-tuffs, tuff-breccias and beds of blocks of basalt. No clastic sedimentary rocks were recorded (Boldreel 2006, this volume).

The deepened Lopra-1/1A re-entry well had no direct hydrocarbon exploration objectives and, as a technical consequence, other types of investigations took priority over petroleum geochemistry. This was particularly the case since no sedimentary rocks were penetrated and neither were any evident shows detected during drilling. Accordingly, the analytical programme carried out with respect to petroleum geochemistry was somewhat limited in scope and character.

Previously, various indications had been recorded of the presence of hydrocarbons in the original Lopra-1 well prior to deepening (Jørgensen 1984; Laier et al. 1997):

1. During drilling in 1981, a gas show was noted at 2008 $\mathrm{m}$ bRKB and 'wax'/bitumen was observed on zeolites.

2. In 1983, gas at a pressure of 19 bar was sampled at the wellhead. The gas flowed at approximately $1 \mathrm{~m}^{3}$ per day and consisted of methane (72\%), N2 (27\%), and traces of higher hydrocarbons (Jacobsen \& Laier 1984). 
Table 1. Sample identification, solvent extraction and gas chromatographic key data

\begin{tabular}{|c|c|c|c|c|c|c|c|c|c|c|}
\hline Sample & $\begin{array}{l}\text { Depth } \\
\text { (m b. KB) }\end{array}$ & Lithology & Comment & $\begin{array}{l}\text { Extract } \\
\text { recovery } \\
(\mathrm{mg})\end{array}$ & $\begin{array}{l}\text { Asphalt- } \\
\text { enes }^{\mathrm{a}}\end{array}$ & $\begin{array}{l}\text { Satur- } \\
\text { ates }^{b}\end{array}$ & $\begin{array}{l}\text { Aro- } \\
\text { matics }\end{array}$ & NSOb & $\mathrm{pr} / \mathrm{ph}^{\mathrm{c}}$ & $C P I^{d}$ \\
\hline RSWC \#51 & 2361 & Vesicular basalt & Entire RSWC immersed in DCM & 1.0 & n.a. & n.a. & n.a. & n.a. & 1.61 & 1.11 \\
\hline RSWC \#45 & 2450 & Basalt & Entire RSWC immersed in DCM & 0.8 & n.a. & n.a & n.a. & n.a. & 1.50 & 1.17 \\
\hline RSWC \#36 & 2570 & Welded tuff & Entire RSWC immersed in DCM & 0.6 & n.a. & n.a. & n.a. & n.a. & 1.52 & n.a. \\
\hline RSWC \#33 & 2630 & Welded tuff & Entire RSWC immersed in DCM & 0.8 & n.a. & n.a. & n.a. & n.a. & 1.41 & n.a. \\
\hline RSWC \#24 & 3076 & Basalt & Entire RSWC immersed in DCM & 0.7 & n.a. & n.a. & n.a. & n.a. & 1.36 & n.a. \\
\hline RSWC \#13 & 3438 & Lapillic tuff & Entire RSWC immersed in DCM & 1.1 & n.a. & n.a. & n.a. & n.a. & 1.34 & n.a. \\
\hline RSWC \#1 & 3543 & Tuff w. calcite vug & Entire RSWC immersed in DCM & n.d. & n.a. & n.a. & n.a. & n.a. & 1.38 & n.a. \\
\hline RSWC \#1 & 3543 & Tuff w. calcite vug & $\begin{array}{l}\text { Calcite vug dissolved in } \mathrm{HCl} \text {, organic } \\
\text { extract recovered by shaking with } \mathrm{DCM}\end{array}$ & 1.1 & 27.3 & n.a. & n.a. & n.a. & 1.02 & 1.24 \\
\hline RSWC \#1 & 3543 & Tuff w. calcite vug & $\begin{array}{l}\text { Tuff chip, counterpart of calcite vug, } \\
\text { crushed and extracted }\end{array}$ & 6.3 & 76.2 & 22.2 & 11.1 & 66.7 & 1.20 & 1.33 \\
\hline Drilling mud & 2900 & & $\begin{array}{l}\text { Approximately } 10 \mathrm{~g} \text { of drilling mud before } \\
\text { addition of diesel, rinsed by DCM }\end{array}$ & 5.7 & 7.0 & 67.3 & 19.2 & 13.5 & 1.15 & 1.17 \\
\hline Drilling mud & 3200 & & $\begin{array}{l}\text { Approximately } 10 \mathrm{~g} \text { of drilling mud after } \\
\text { addition of diesel, rinsed by DCM }\end{array}$ & 23.9 & 2.5 & 68.0 & 22.2 & 9.9 & 1.66 & 1.05 \\
\hline Pipe dope & & & $\begin{array}{l}\text { Anti-seize compound for drilling rods } \\
\text { sample supplied by DANOP }\end{array}$ & n.a. & 2.1 & 57.8 & 24.5 & 17.7 & n.a. & n.a. \\
\hline
\end{tabular}

$\mathrm{a}$ in $w t \%$ of total extract.

$\mathrm{b}$ in wt\% of maltene fraction.

c pristane/phytane ratio, from gas chromatography.

$d$ carbon preference index, calculated over the interval $\mathrm{nC}_{22-32}$.

In addition, water with an oil-film was produced by the well, but the oil film was not analysed in detail. Based on its isotopic composition, it was concluded that the gas was principally of thermogenic origin, although the gas was unusually 'dry' (Laier et al. 1997).

3. In 1992, oil-film on water from the well was sampled, and minor amounts of gas escaped from the wellhead. Based on geochemical analysis, it was suggested that the oil originated from a mature siliciclastic source rock, which was presumed to be present below the basaltic cover (Laier et al. 1997).

4. During a VSP-survey in 1994, a logging tool was lowered into the well and a thick, oil-smelling mud-slurry was observed sticking to the tool and wire when returned to the surface. Minor amounts of gas were noted. Analysis of the slurry revealed the presence of petroleum components similar to those detected in water samples from the well.

Moreover, wax-coatings on zeolite minerals have been recorded in several outcrops on the Faroe Islands (Jørgensen 1984; Laier et al. 1997).

In order to check if these indications of the presence of petroleum in the Lopra-1 well prior to deepening could be further substantiated, a minor petroleum geochemical analytical programme was carried out on samples from the deepened well, the results of which are reported below.
RSWC: rotary sidewall core.

DCM: dichloromethane.

n.a.: not analysed.

n.d.: not detected.

KB: Kelly Bushing.

\section{Samples and methods}

Since the Lopra-1/1A re-entry well was drilled as a stratigraphic test, samples were principally reserved for investigations directly related to the main objectives of the programme, and petroleum geochemical studies were generally restricted to non-destructive analyses. Hence, samples could not be crushed and analyses had to rely on organic matter extracted from the surface and the directly accessible pore-spaces of the recovered rock samples. This procedure is necessarily sub-optimal, since, as will be demonstrated, the risk of contamination is overwhelming. However, for pre-determined reasons other types of investigations had been assigned greater priority.

All analyses were carried out on rotary sidewall cores (RSWC), 58 of which were collected over the section penetrated in the deepened well below the TD of the original Lopra-1 well, i.e. deeper than $2178 \mathrm{~m}$ bRKB. All samples consisted of basaltic volcanics, i.e. lavas, tuffs and hyaloclastic breccias.

Upon receipt, all RSWC samples, which came in screwcap glass containers, were taken to a darkroom and checked by organolfactoric means for petroleum odour, and for visible fluorescence by means of a hand-held UV-lamp. Based on the presence of a distinct petroleum odour and weak to clear fluorescence, seven samples were selected for further study (Table 1). 
In order to preserve the samples intact for other investigations, extracts were recovered from the surface and the immediately accessible pore spaces of the samples by immersing entire RSWCs into dichloromethane (DCM) for approximately 15 minutes in a glass beaker placed in an ultrasonification device. Rock fragments were separated by centrifugation, DCM was removed by evaporation, and the recovery was determined by weighing.

Due to very low recoveries, no further preparative procedures were applied. Total extracts were re-dissolved in isooctane and analysed by gas chromatography (GC) and by coupled gas chromatography - mass spectrometry (GCMS).

RSWC \#1 (3543 m) was treated as described above, but a small chip containing a calcite-filled vug was removed from the sample. The vug was dissolved in dilute hydrochloric acid $(\mathrm{HCl}, 2 \mathrm{~N})$, and an organic extract was recovered by several stages of shaking the solute with dichloromethane (DCM) in a separatory funnel (Table 1). The basaltic counterpart of the vug was coarsely crushed and extracted for four hours in a Soxtec apparatus (1h reflux in DCM, followed by $3 \mathrm{~h}$ rinsing). Asphaltenes were precipitated from both extracts by addition of 40 -fold excess of $n$-pentane, and the maltenes were separated into saturated, aromatic and polar compounds by Medium Pressure Liquid Chromatography (MPLC), using a method modified from Radke et al. (1980). Saturate fractions were analysed by GC and GC-MS.

In order to remedy problems with a stuck pipe, diesel was added to the well at a depth of approximately 3100 $\mathrm{m}$. Neither samples of the diesel, nor of the drilling mud, were preserved for analysis. Instead, drilling mud from bagged drill cutting samples collected before and after addition of diesel were analysed in order to check for possible contamination. Approximately $10 \mathrm{~g}$ of sample (drilling mud plus cuttings) were ultrasonically extracted with DCM (app. $100 \mathrm{ml}$ ). Extracts were recovered by decantation and centrifugation, and the DCM removed by evaporation. Asphaltenes were precipitated by addition of 40fold excess of $n$-pentane, with the maltenes being separated into saturated, aromatic and polar components as described above. The saturate fractions were analysed by GC and GC-MS.

An additional possible source of contamination was pipe dope, an anti-seize compound used when joining drilling rods. A sample of the pipe-dope used during drilling of the Lopra-1/1A re-entry well was supplied by DANOP and analysed using standard procedures for oil analysis. Asphaltenes were precipitated by addition of 40 -fold excess of $n$-pentane, and the maltenes were separated into saturated, aromatic and polar components as described above. Again the saturate fractions were analysed by GC and GC-MS.

Gas chromatographic analyses were carried out by means of a Hewlett-Packard 5890 Series II plus gas chromatograph, using splitless injection, a 25 HP-1 WCOT column and a flame ionisation detector (FID).

Biological marker analyses were carried out by means of a Hewlett-Packard 5980A Series II gas chromatograph interfaced to a Hewlett-Packard 5971 mass selective detector (MSD) using splitless injection and a $25 \mathrm{~m} \mathrm{HP}-5$ WCOT column.

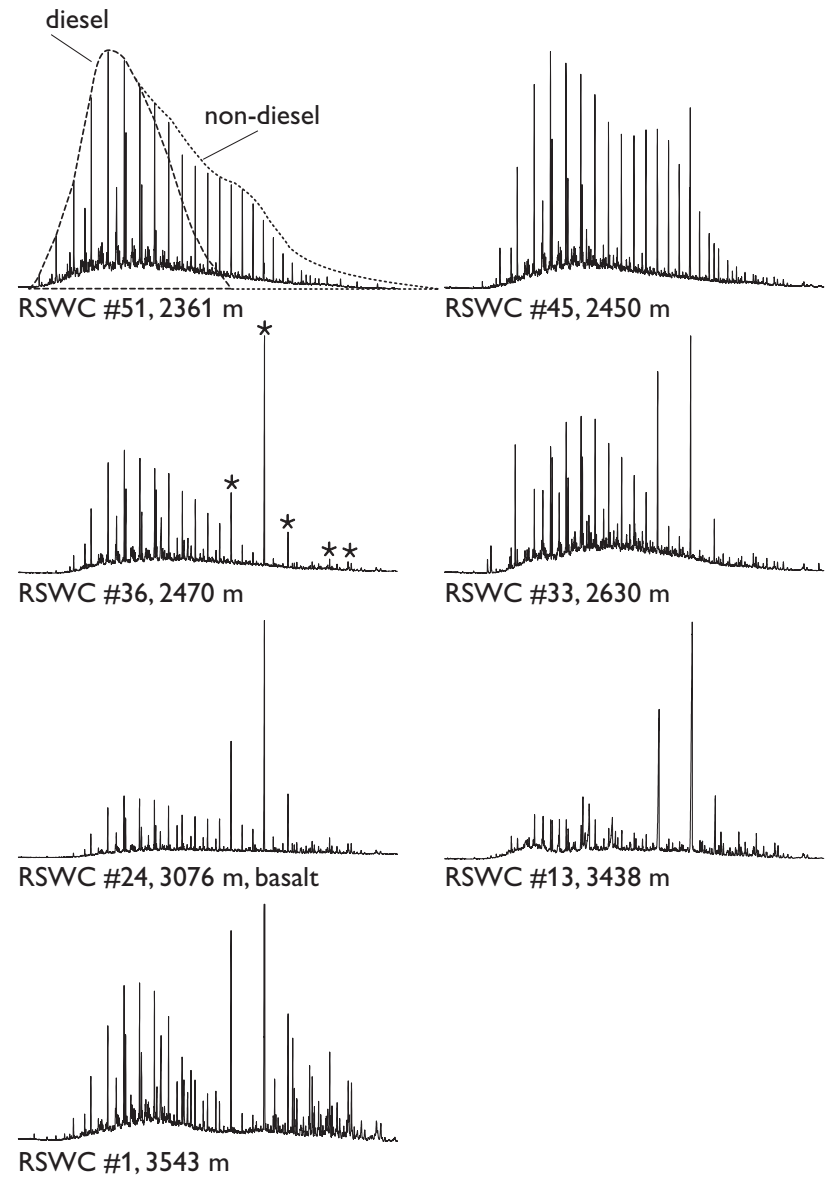

Fig. 1. Gas chromatograms obtained from analysis of RSWCs rinsed in DCM. Approximate shapes and positions of 'diesel' and 'nondiesel' envelopes are shown in sample RSWC \#51. Examples of 'prominent unknowns' are indicated by asterisks in sample RSWC \#36, see Fig. 3. Note that all samples show some degree of diesel contamination, although this adulterant was not added until a depth of approximately $3100 \mathrm{~m}$. This observation suggests that diesel contamination is pervasive throughout the entire uncased section of the well. 

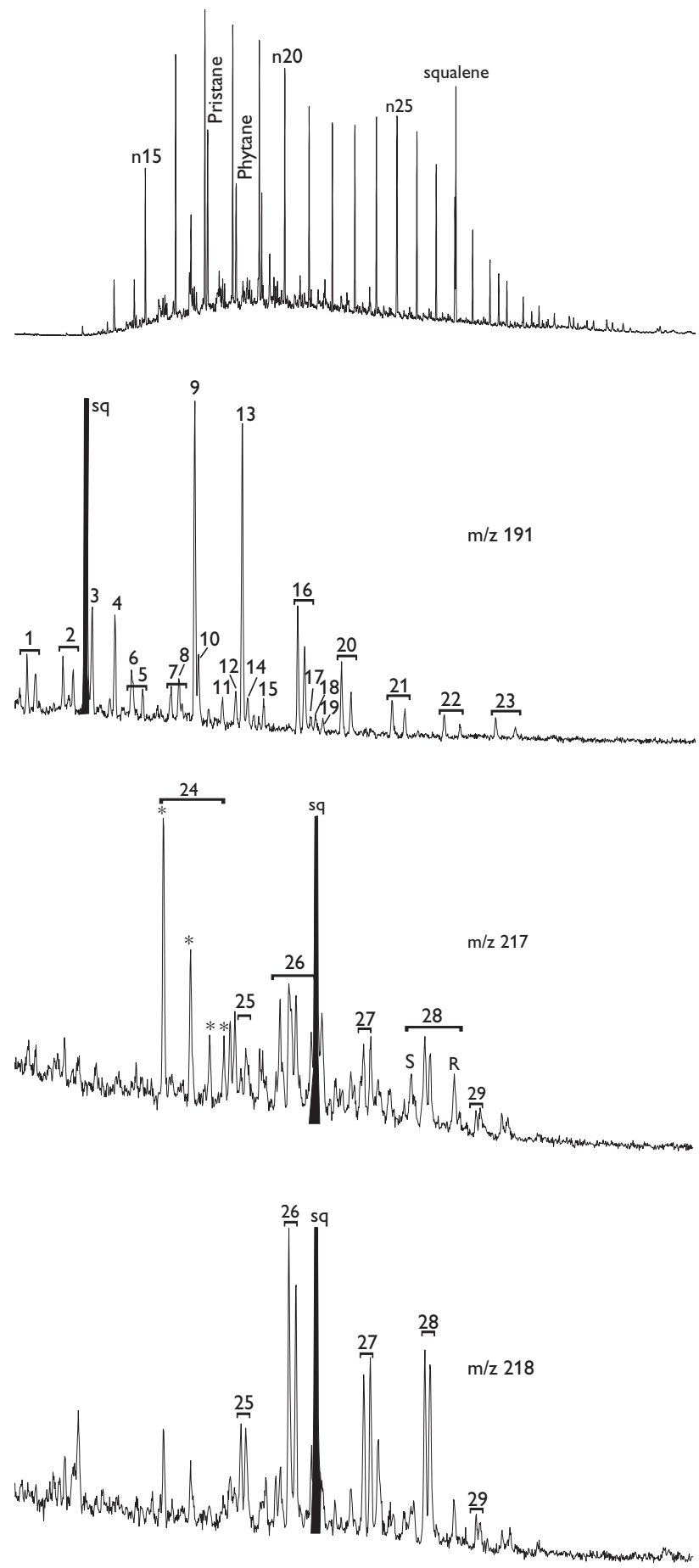

Fig. 2. Gas chromatogram and representative ion fragmentograms $\mathrm{m} / \mathrm{z} 191, \mathrm{~m} / \mathrm{z} 217$ and m/z 218 (sample RSWC \#45, $2450 \mathrm{~m}$ ). Filled black peak labelled 'sq' is the contaminant squalene - a compound found on the skin of humans. Compound identification is shown in Table 5.

\section{Results}

\section{RSWCs rinsed in DCM}

Total extract recoveries were generally close to $1 \mathrm{mg}$, and no attempt was made to fractionate the residues. Gas chromatograms of the bulk extracts (Fig. 1) show that most samples contain a more or less well-developed series of $n$-alkanes. The distributions are generally light-end skewed and unimodal, but two samples show evidence of bimodal distributions with higher proportions of waxy $(22+)$ $n$-alkanes. Pristane/phytane ratios range from 1.34 to 1.61, and no odd- or even-number predominance is noted among the $n$-alkanes. In addition to $n$-alkanes, a number of prominent peaks of unknown identity are noted in all but one of the chromatograms, see below. Key parameters are listed in Table 1.

Biological marker maturity indications are consistent, with homohopane and bishomohopane 22S/(22S + 22R) epimerisation ratios at equilibrium (i.e. close to 0.60 ), and $\mathrm{C}_{29}$ sterane $20 \mathrm{~S} /(20 \mathrm{~S}+20 \mathrm{R})$ epimerisation ratios slightly below equilibrium (i.e. slightly less than 0.52 ), indicating early to mid oil-window maturity (Table 2). Sterane and triterpane biological marker distributions display only minor variations among the samples. Representative ion fragmentograms m/z 191, m/z217, and m/z218 are shown in Fig. 2, with key biological marker parameter ratios tabulated in Tables 3, 4. Triterpane distributions generally comprise fairly high proportions of tricyclic triterpanes. Among the pentacyclics the presence of 30-norhopanes plus 25norhopanes is noted together with a peak eluting fractionally earlier than hopane. This peak is routinely assigned to $18 \alpha(\mathrm{H})$-oleanane, a well-known marker of angiosperm higher plant inputs, and hence of source ages younger than the mid Cretaceous. However, scan-mode mass spectrometric analysis could not confirm the identity of this compound. Rather the peak represents several co-eluting compounds, probably comprising oleanane, lupane, and one or more unknowns. Limited amounts of sample precluded further investigation of this problem of identification. Norhopane to hopane ratios are close to unity and extended hopanes are relatively abundant. Moreover, gammacerane and notable proportions of hexahydrobenzohopane are present.

Sterane distributions are very similar for all samples, comprising a clear predominance of $\mathrm{C}_{27}$ steranes over the $\mathrm{C}_{28}$ plus $\mathrm{C}_{29}$ steranes, but with the co-occurrence of $\mathrm{C}_{30}$ as well as of $\mathrm{C}_{26}$ steranes. Prominence of $\beta \beta$-sterane epimers is noted in both the $\mathrm{m} / \mathrm{z} 217$ and $\mathrm{m} / \mathrm{z} 218$ ion fragmentograms.

A number of prominent unknowns are noted in the 


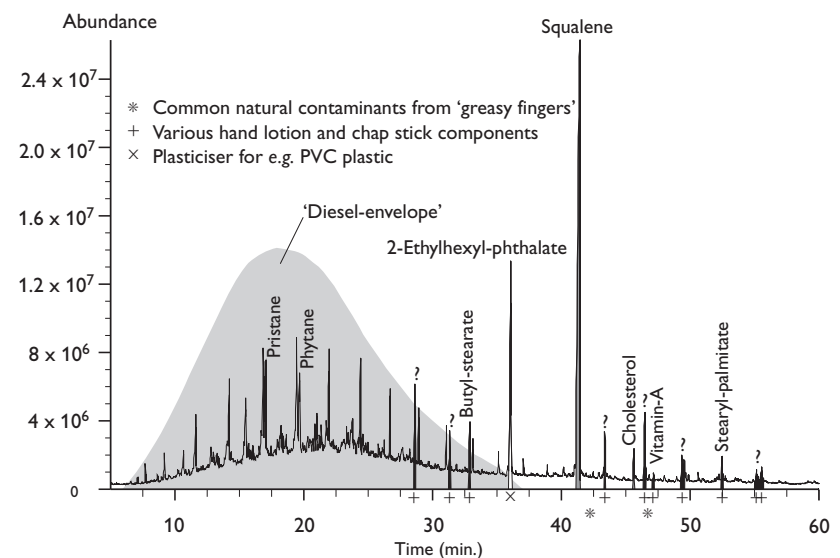

Fig. 3. Full scan total ion fragmentogram, RSWC \#1. The approximate shape and position of a 'diesel envelope' are shown by shading. Interpretation of the origins of various contaminants is shown.

gas chromatograms as described above. Scan-mode mass spectrometric analyses of the extract obtained from RSWC \#1, in which these compounds are particularly abundant, identifies: squalene and cholesterol; 2-ethylhexyl-phthalate; vitamin A and various esters such as butyl-stearate, stearyl-palmitate and a series of similar compounds (Fig.3).

\section{Calcite vug dissolved in $\mathrm{HCl}$ and basalt coarsely crushed}

Total extract recovery of the acid-digested calcite vug was only $1.1 \mathrm{mg}$, whereas solvent extraction of the tuff hostrock yielded $6.3 \mathrm{mg}$. The comparatively high extraction yield of the latter sample is probably due to the more efficient extraction procedure, i.e. crushing and Soxtec extraction as opposed to ultrasonical extraction of entire samples.

Gas chromatograms of saturate fractions of the two sub-samples (Fig. 4) are different. The extract recovered from the acid-digested calcite vug shows a strongly unimodal $n$-alkane distribution, centred around $\mathrm{C}_{20}$, with notable light-end depletion and a rather poor signal-tonoise ratio. The basalt extract shows a well-developed unimodal distribution of $n$-alkanes, centred around $\mathrm{C}_{17}$, and a clear odd-predominancein the $\mathrm{C}_{25-32}$ range. Pristane/phytane ratios are 1.02 and 1.20 , respectively.

Biological marker distributions are similar in the two samples, although the signal-to-noise ratio observed in the acid-digested sample is rather poor (Fig. 4). These distributions are significantly different from the picture provided by other samples, including both sidewall cores (see above), drilling mud and pipe dope (see below). Triterpane distributions comprise low proportions of tricyclic triterpanes. Amongst the pentacyclics the presence of 28,30-bisnorhopane is noted, while 30-norhopanes, 25norhopanes, and 'oleanane' are absent, or cannot be identified with any degree of certainty. $\mathrm{H} 29 / \mathrm{H} 30$ ratios are close to 0.3 and extended hopanes are relatively scarce. Regular sterane distributions comprise a clear predominance of $\mathrm{C}_{27}$ steranes over the $\mathrm{C}_{28}$ plus $\mathrm{C}_{29}$ homologues with the presence of $\mathrm{C}_{30}$ as well as $\mathrm{C}_{26}$ steranes.

\section{Drilling mud}

Total extract recovery from the drilling mud samples differs widely before and after the addition of diesel to the drilling mud at a depth of approximately $3100 \mathrm{~m}$ bRKB (Table 1). This difference recurs in the gas chromatograms of saturate fractions of the two samples (Fig. 5). The sample collected before addition of diesel yields a rather irregular light-end skewed $n$-alkane distribution with high proportions of 'Unresolved Complex Mixture' (UCM). The sample collected after addition of diesel yields a well-defined, nearly symmetrical, unimodal $n$-alkane distribution, centred around $\mathrm{C}_{16}$. Pristane/phytane ratios are 1.15 and 1.66 , respectively.

Except for a minor enhancement of $\mathrm{C}_{27}$ diasteranes, and a slightly more pronounced enhancement of low molecular weight tricyclic triterpanes in the diesel-containing sample, biological marker distributions, however, are similar in the two samples and indistinguishable from

Table 2. Biological marker maturity data

\begin{tabular}{lcccc}
\hline Sample & $\begin{array}{c}\mathrm{S} 29 \\
\mathrm{~S} /(\mathrm{S}+\mathrm{R})^{\mathrm{a}}\end{array}$ & $\begin{array}{c}\mathrm{S} 29 \\
\beta \alpha /(\beta \beta+\alpha \alpha)^{\mathrm{b}}\end{array}$ & $\begin{array}{c}\mathrm{H} 31 \\
\mathrm{~S} /(\mathrm{S}+\mathrm{R})^{\mathrm{c}}\end{array}$ & $\begin{array}{c}\mathrm{H} 32 \\
\mathrm{~S} /(\mathrm{S}+\mathrm{R})^{\mathrm{d}}\end{array}$ \\
\hline RSWC \#51 & 0.49 & 0.62 & 0.61 & 0.63 \\
RSWC \#45 & 0.48 & 0.60 & 0.59 & 0.61 \\
RSWC \#36 & 0.46 & 0.60 & 0.60 & 0.60 \\
RSWC \#33 & 0.43 & 0.63 & 0.59 & 0.63 \\
RSWC \#24 & 0.48 & 0.61 & 0.56 & 0.59 \\
RSWC \#13 & 0.49 & 0.60 & 0.57 & 0.60 \\
RSWC \#1 & 0.47 & 0.60 & 0.59 & 0.59 \\
RSWC \#1 & 0.44 & 0.58 & 0.58 & 0.59 \\
RSWC \#1 & 0.51 & 0.54 & 0.58 & 0.61 \\
Drilling mud $^{\mathrm{e}}$ & 0.45 & 0.61 & 0.59 & 0.62 \\
Drilling mud $^{\mathrm{f}}$ & 0.50 & 0.64 & 0.59 & 0.59 \\
Pipe dope $^{\text {Rip }}$ & 0.42 & 0.42 & 0.65 & 0.57 \\
\hline
\end{tabular}

${ }^{\mathrm{a}} \mathrm{C}_{29}$ regular sterane $\alpha \alpha 20 \mathrm{~S} /(\alpha \alpha 20 \mathrm{~S}+\alpha \alpha 20 \mathrm{R})$ epimer ratio.

${ }^{\mathrm{b}} \mathrm{C}_{29}$ regular sterane $\beta \beta /(\beta \beta+\alpha \alpha)$ epimer ratio.

c homohopane $22 \mathrm{~S} /(22 \mathrm{~S}+22 \mathrm{R})$ epimer ratio.

${ }^{\mathrm{d}}$ bishomohopane $22 \mathrm{~S} /(22 \mathrm{~S}+22 \mathrm{R})$ epimer ratio.

e before addition of diesel.

$f$ after addition of diesel.

RSWC: rotary sidewall core. 
Table 3. Key triterpane biological marker parameter ratio

\begin{tabular}{lccccc}
\hline Sample & $\mathrm{T} 23 / \mathrm{H} 30^{\mathrm{a}}$ & $\mathrm{Ts} /(\mathrm{Ts}+\mathrm{Tm})^{\mathrm{b}}$ & $\mathrm{H} 28 / \mathrm{H} 29^{\mathrm{c}}$ & $\mathrm{H} 29 / \mathrm{H} 30^{\mathrm{d}}$ & $\mathrm{OL} / \mathrm{H} 30^{\mathrm{e}}$ \\
\hline RSWC \#51 & 0.93 & 0.49 & 0.00 & 0.96 & 0.00 \\
RSWC \#45 & 1.00 & 0.52 & 0.00 & 1.06 & 0.14 \\
RSWC \#36 & 1.00 & 0.52 & 0.00 & 0.96 & 0.18 \\
RSWC \#33 & 1.14 & 0.54 & 0.00 & 0.93 & 0.14 \\
RSWC \#24 & 1.00 & 0.57 & 0.00 & 1.01 & 0.52 \\
RSWC \#13 & 1.06 & n.a. & 0.00 & 0.96 & 0.80 \\
RSWC \#1 & 0.64 & n.a. & 0.00 & 0.94 & 0.36 \\
RSWC \#1 & 0.13 & 0.43 & 0.35 & 0.33 & 0.00 \\
RSWC \#1 & 0.12 & 0.44 & 0.37 & 0.28 & 0.00 \\
Drilling mud $^{\mathrm{f}}$ & 0.50 & 0.51 & 0.00 & 0.99 & 0.03 \\
Drilling mud $^{g}$ & 1.28 & 0.51 & 0.00 & 1.02 & 0.04 \\
Pipe dope $^{2}$ & 0.44 & 0.41 & 0.00 & 0.12 & 0.16 \\
\hline
\end{tabular}

${ }^{a} \mathrm{C}_{23}$ tricyclic terpane to hopane ratio.

${ }^{\mathrm{b}}$ Ts: $18 \alpha(\mathrm{H})$-trisnorneohopane, Tm: trisnorhopane.

${ }^{c} \mathrm{H} 28$ : 28,30-bisnorhopane, H29: norhopane.

${ }^{\mathrm{H}} \mathrm{H}$ 29: norhopane, $\mathrm{H} 30$ : hopane.

e OL: $18 \alpha(\mathrm{H})$-oleanane, H30: hopane.

${ }^{f}$ before addition of diesel.

${ }^{g}$ after addition of diesel.

n.a.: not analysed.

RSWC: rotary sidewall core.

the biological marker distributions yielded by RSWCs rinsed in DCM (Fig. 5).

\section{Pipe dope}

The gas chromatogram of the saturate fraction does not allow identification of any components, but simply shows a large hump of 'Unresolved Complex Mixture' (Fig. 6).

Biological marker maturity parameters indicate early to mid-oil window maturity (Table 2). Triterpane distributions generally comprise high proportions of tricyclic triterpanes, and among the pentacyclics the presence of 30 -norhopanes plus abundant 25-norhopanes is noted together with a peak eluting fractionally earlier than hopane, probably representing several co-eluting compounds. These possibly comprise oleanane, lupane and one or more unknowns (Fig. 6). The H29/H30 ratio is 1.12 with extended hopanes being abundant. Gammacerane and notable proportions of hexahydrobenzohopane are present.

The distribution of regular steranes shows a clear predominance of $\mathrm{C}_{27}$ steranes over the $\mathrm{C}_{28}$ and $\mathrm{C}_{29}$ homologues plus the presence of $\mathrm{C}_{30}$ as well as $\mathrm{C}_{26}$ steranes. Prominence of $\beta \beta$-sterane epimers is noted in both the $\mathrm{m} / \mathrm{z} 217$ and $\mathrm{m} / \mathrm{z} 218$ ion fragmentograms.
Table 4. Key sterane biological marker parameter ratios

\begin{tabular}{lcccccc}
\hline Sample & D27/S27 & S28 (\%) & S27 (\%) & S29 (\%) & S27/S29 & S30 \\
\hline RSWC \#51 & 1.33 & 19.0 & 50.8 & 30.2 & 1.7 & present \\
RSWC \#45 & 1.27 & 21.3 & 46.7 & 32.0 & 1.5 & present \\
RSWC \#36 & 1.39 & 23.0 & 46.0 & 31.0 & 1.5 & present \\
RSWC \#33 & 1.53 & 20.0 & 50.0 & 30.0 & 1.7 & present \\
RSWC \#24 & 1.20 & 19.56 & 51.0 & 29.4 & 1.7 & present \\
RSWC \#13 & 1.22 & 21.7 & 47.8 & 30.4 & 1.6 & present \\
RSWC \#1 & 0.95 & 22.4 & 47.4 & 30.3 & 1.6 & present \\
RSWC \#1 & 1.04 & 21.3 & 46.8 & 31.9 & 1.5 & present \\
RSWC \#1 & 1.06 & 21.4 & 48.2 & 30.4 & 1.6 & present \\
Drilling mud & 0.81 & 19.5 & 47.0 & 33.5 & 1.4 & present \\
Drilling mud & 1.19 & 24.6 & 45.9 & 29.5 & 1.6 & present \\
Pipe dope & 0.47 & 23.8 & 43.3 & 32.8 & 1.3 & present \\
\hline
\end{tabular}

a (sum $\mathrm{C}_{27}$ diateranes)/(sum $\mathrm{C}_{27}$ regular steranes), m/z 217.

b relative distribution of $C_{27-29}$ regular steranes, based on $\alpha \alpha 20 R$ epimers in $\mathrm{m} / \mathrm{z} 217$.

${ }^{c} \mathrm{C}_{27} / \mathrm{C}_{29}$ regular sterane ratio, based on $\alpha \alpha 20 \mathrm{R}$ epimers in $\mathrm{m} / \mathrm{z} 217$.

${ }^{\mathrm{d}} \mathrm{C}_{30}$ regular steranes.

e before addition of diesel.

$\mathrm{f}$ after addition of diesel.

RSWC: rotary sidewall core.

\section{Discussion}

The amounts of extract recovered from the RSWC samples are generally very low, which naturally limits the possibilities for detailed studies and implementation of extensive sample preparation techniques in order to optimise the quality of analytical data obtained. Furthermore, since total recoveries are low, even minor random contamination, which normally would be insignificant and ignored, may cause notable problems. Hence, considerable uncertainty is attached to the conclusions made on the basis of the analyses reported here.

Analyses of mud samples collected before and after addition of diesel show a profound influence of diesel on the content and distribution of $n$-alkanes, whereas the biological marker characteristics, except for minor enhancement of $\mathrm{C}_{27}$ diasteranes and low molecular weight tricyclic triterpanes, are largely unaffected. Hence for most practical purposes, this particular diesel distillate fraction will not severely influence any of the biomarker ratios. The biomarker distributions observed in the two mud samples are largely identical to the distributions yielded by DCM-rinsed RSWC samples.

Based on gas chromatography data, most DCM-rinsed RSWC samples are seen to contain diesel, but some extracts also contain longer chain-length $n$-alkanes and biological markers which are unlikely to originate from diesel contamination. In addition to diesel, contamination from various other sources is present in most samples: 

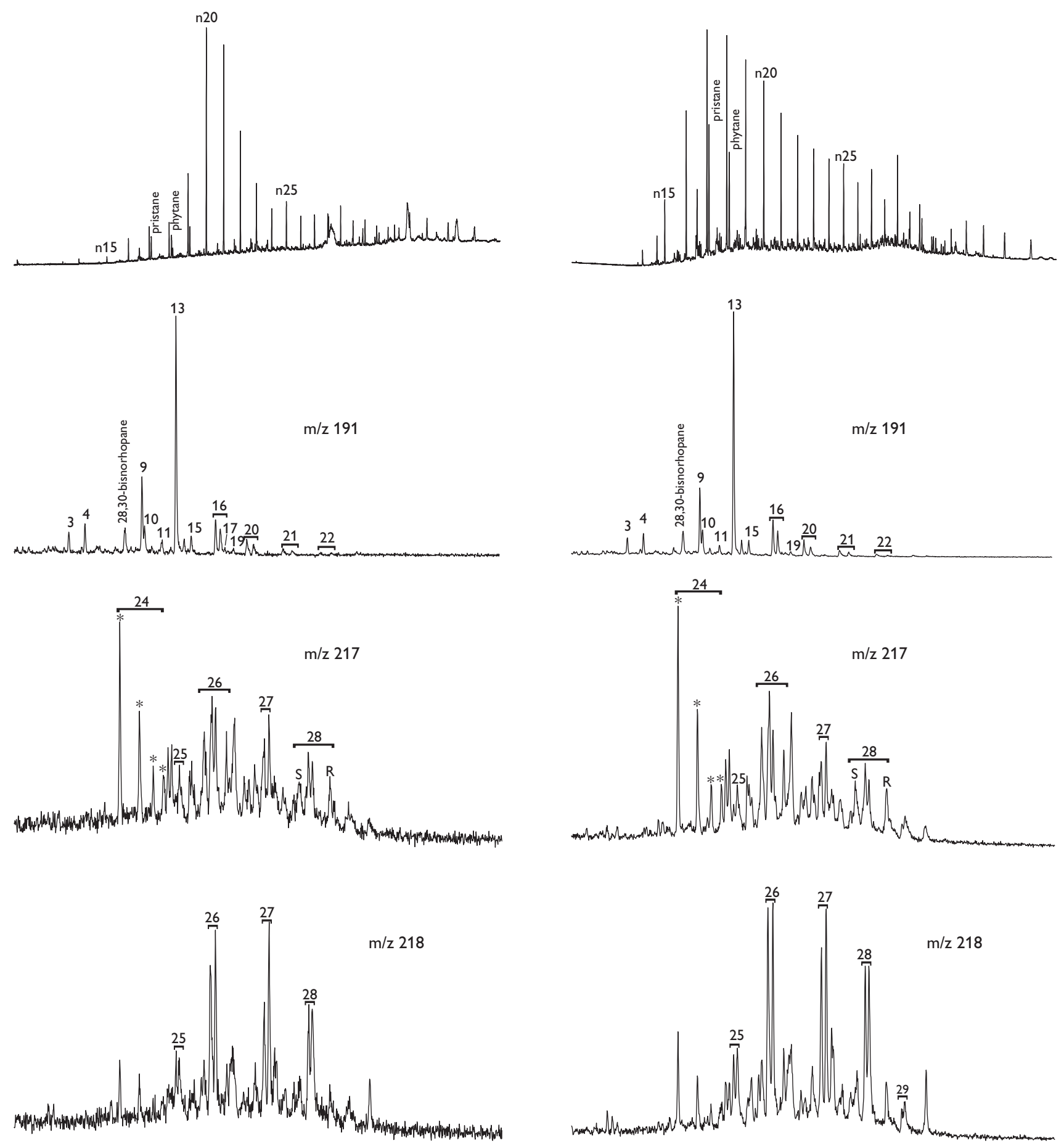

Fig. 4. Gas chromatograms and ion fragmentograms m/z 191, m/z 217 and m/z 218, RSWC \#1, calcite vug dissolved in $\mathrm{HCl}$ (left), and its coarsely crushed tuff host rock (right). Note mutual similarity of biological marker distributions and differences when compared to distributions shown in Figs 2, 5, 6. Compound identification is shown in Table 5. 

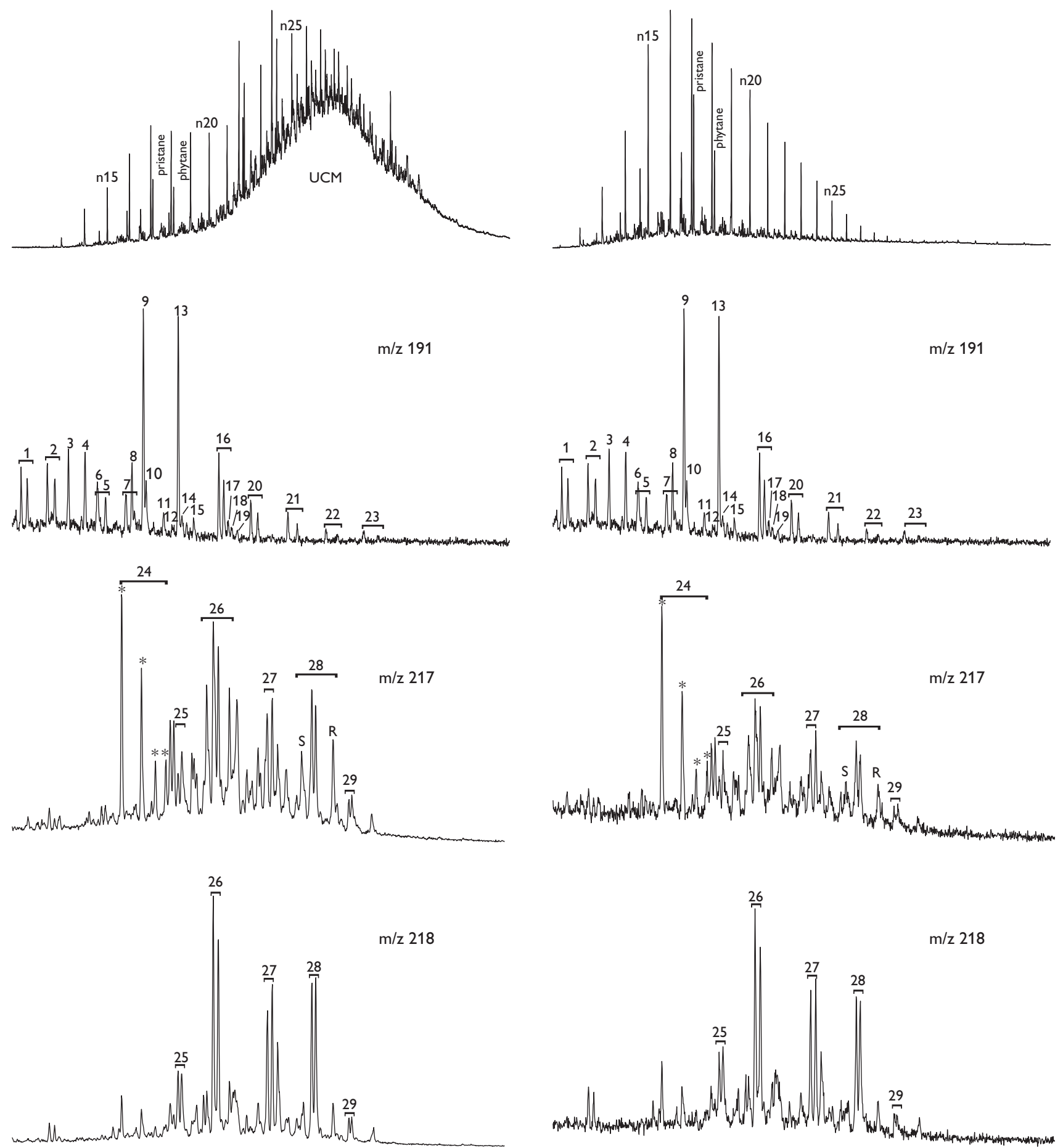

Fig. 5. Gas chromatograms and ion fragmentograms m/z 191, m/z 217 and m/z 218, extract of drilling mud before addition of diesel (left), and extract of drilling mud after addition of diesel (right). UCM, Unresolved Complex Mixture. Note profound influence of diesel on the $n$-alkane distribution, and the lack of, or limited effect on, biological marker distributions. Compound identification is shown in Table 5. 
squalene and cholesterol are commonly occurring natural compounds present on the skin of humans, for instance on the hands ('naturally greasy fingers'); 2-ethylhexyl-phthalate is a widely used plasticiser for various polymers; vita$\min \mathrm{A}$, esters such as butyl-stearate, stearyl-palmitate and similar compounds detected in the sample are commonly used in cosmetics, including hand lotion and chap-stick.

The absence of both acyclic isoprenoids and $n$-alkanes from pipe dope plus the presence of abundant 25-norhopanes suggest that this product is based on a heavily biodegraded oil (corresponding to level 6 of Peters \& Moldowan (1993)). Based on the presence of 30-norhopanes, which is also manifest in norhopane to hopane ratio close to unity plus the prominence of $\beta \beta$-sterane epimers and comparatively high proportions of homohopanes (in particular tetrakishomohopane to pentakishomohopane ratio close to unity), this oil was presumably generated from a marine marly source rock, deposited in a highly anoxic environment. In addition, the presence of angiosperm higher land plant markers such as $18 \alpha(\mathrm{H})$-oleanane suggest a source age younger than the mid-Cretaceous. Normal and acyclic isoprenoid alkanes are absent, but the biological marker distribution shows clear similarities to the distributions yielded by DCM-rinsed RSWCs discussed above, such that the presence of contamination from pipe dope, in addition to adulteration from other sources, seems obvious. However, differences are observed: pipe dope contains very high proportions of 25 -norhopanes, whereas the proportion in the RSWCs are but minor; the relative abundance of Ts and Tm is reversed in pipe dope compared to DCM-rinsed RSWC samples. Similarly, the proportion of $\mathrm{C}_{27}$ diasteranes relative to $\mathrm{C}_{27}$ regular steranes is much lower in pipe dope extracts than in the DCMrinsed RSWC samples. The latter feature may, however, be wholly or partly caused by the addition of diesel, which was shown above to result in minor enhancement of low boiling-range tricyclics and diasteranes relative to noncontaminated samples.

In summary, DCM-rinsed samples are contaminated by a variety of compounds originating from several sources, including diesel, pipe dope, plasticisers, naturally greasy fingers and cosmetics, possibly hand lotion and/or chap stick. However, the samples also contain petroleum components that do not seem to originate from these sources of contamination. An origin from other sources of contamination or from indigenous crude oil is conceivable. Laier et al. (1997) show the presence of traces of heavy petroleum hydrocarbons and wax in samples from the original Lopra-1 well, prior to deepening. The 'unexplainable' petroleum components found in DCM-rinsed samples from the deepened well may represent similar occurrences.
Table 5. Compound identification key

\begin{tabular}{|c|c|}
\hline Level & Compound \\
\hline $\mathrm{n} 15$ & $\mathrm{C}_{15}$ normal alkane \\
\hline a & pristane \\
\hline$b$ & phytane \\
\hline $\mathrm{n} 20$ & $\mathrm{C}_{20}$ normal alkane \\
\hline n25 & $\mathrm{C}_{25}$ normal alkane \\
\hline sq & squalene \\
\hline n30 & $\mathrm{C}_{30}$ normal alkane \\
\hline 1 & $\mathrm{C}_{28}$ tricyclic terpanes ( 2 isomers) \\
\hline 2 & $\mathrm{C}_{29}$ tricyclic terpanes ( 2 isomers) \\
\hline 3 & Ts $=$ trisnorneohopane \\
\hline 4 & $\mathrm{Tm}=$ trisnorhopane \\
\hline 5 & $\mathrm{C}_{30}$ tricyclic terpanes ( 2 isomers) \\
\hline 6 & $\mathrm{C}_{28} 25,30$ bisnorhopane, coeluting with " 5 " \\
\hline 7 & $\mathrm{C}_{31}$ tricyclic terpanes ( 2 isomers) \\
\hline 8 & $\mathrm{C}_{29} 25$-norhopane, partially coeluting with "7" \\
\hline 9 & norhopane $=30$-norhopane \\
\hline 10 & $29 \mathrm{Ts}=$ norneohopane \\
\hline 11 & normoretane \\
\hline 12 & mixture of oleanane, lupane and unknown \\
\hline 13 & hopane \\
\hline 14 & $\mathrm{C}_{30} 30$-norhopane \\
\hline 15 & moretane \\
\hline 16 & homohopane, $22 \mathrm{~S}$ and $22 \mathrm{R}$ isomers \\
\hline 17 & gammacerane \\
\hline 18 & $\mathrm{C}_{31}$ hexahydrobenzohopane \\
\hline 19 & homomoretane \\
\hline 20 & bishomohopane, $22 \mathrm{~S}$ and $22 \mathrm{R}$ isomers \\
\hline 21 & trishomohopane, $22 \mathrm{~S}$ and $22 \mathrm{R}$ isomers \\
\hline 22 & tetrakishomohopane, $22 \mathrm{~S}$ and $22 \mathrm{R}$ isomers \\
\hline 23 & pentakishomohopane, $22 \mathrm{~S}$ and $22 \mathrm{R}$ isomers \\
\hline 24 & $\mathrm{C}_{27}$ diasteranes, 4 isomers labelled with asterisks \\
\hline 25 & $\mathrm{C}_{26}$ regular steranes, $\beta \beta$ isomers only \\
\hline 26 & $\mathrm{C}_{27}$ regular steranes, $\alpha \alpha$ and $\beta \beta$ isomers \\
\hline 27 & $\mathrm{C}_{28}$ regular steranes, $\beta \beta$ isomers only \\
\hline 28 & $\mathrm{C}_{29}$ regular steranes, $\alpha \alpha \mathrm{S}, \alpha \alpha \mathrm{R}$ and $\beta \beta$ isomers \\
\hline 29 & $\mathrm{C}_{30}$ regular steranes, $\beta \beta$ isomers only \\
\hline
\end{tabular}

Biological marker, in particular triterpane, distributions in extracts recovered from DCM-rinsing of RSWC samples from the deepened Lopra- 1 well show a number of striking similarities to distributions yielded by certain samples collected in the original Lopra-1 well prior to re-entry. These samples include petroleum extracted from water samples in 1992 (Laier et al. 1997), and a sample collected from slurry sticking to a VSP-tool, which was lowered into the hole in 1994. The biological marker characteristicsinclude features such as the presence of 30 -norhopanes, 25-norhopanes, gammacerane, hexahydrobenzohopane, $\mathrm{H} 29 / \mathrm{H} 30$ ratios close to or greater than 1 and a high relative abundance of extended hopanes plus prominence of the $\beta \beta$-sterane epimers. Minor differences between pipe dope and the 'slurry' and the oil film are also observed, principally with respect to the presence of $n$-alkanes and the proportions of $\mathrm{C}_{28}$ regular steranes relative to the pro- 

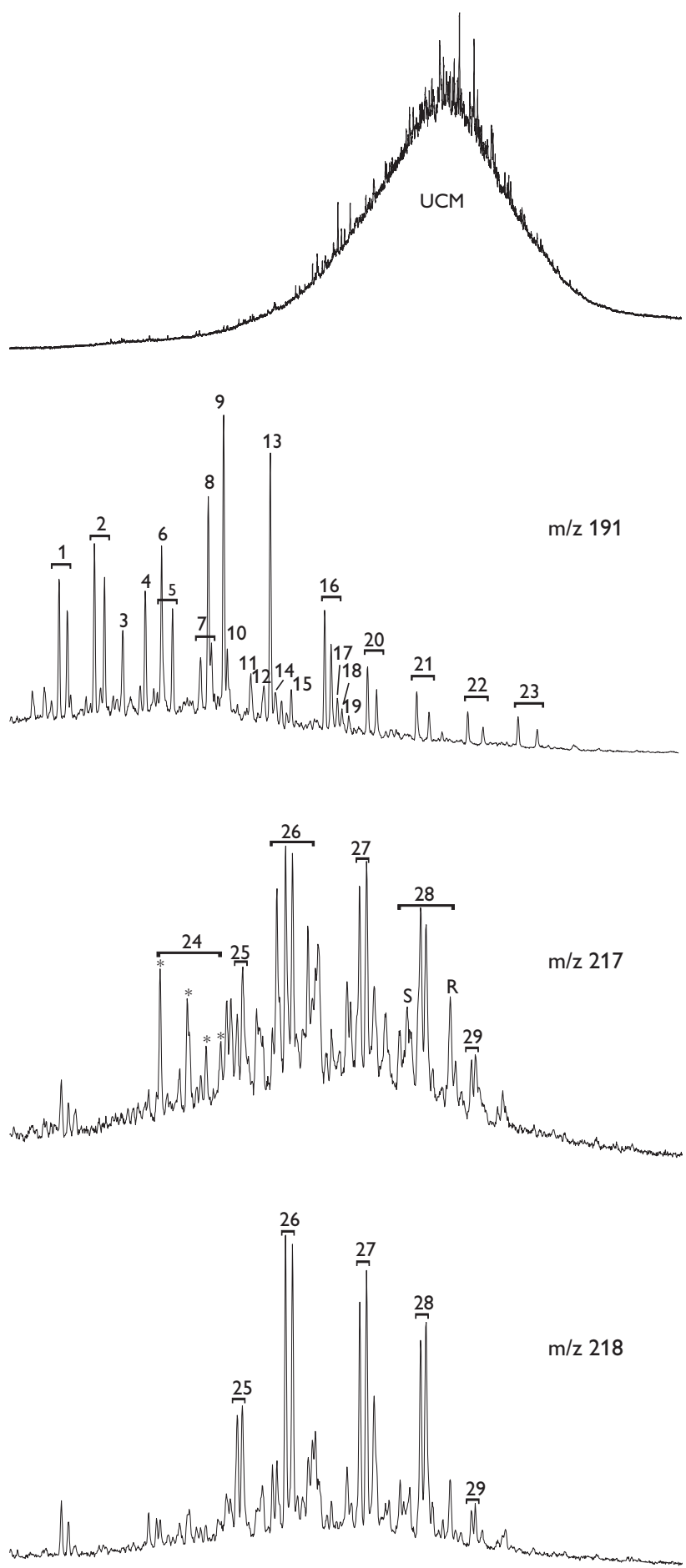

Fig. 6. Gas chromatogram and ion fragmentograms m/z 191, m/z 217 and m/z 218, pipe dope. UCM, Unresolved Complex Mixture. Compound identification is shown in Table 5.

portions of $\mathrm{C}_{27}$ and $\mathrm{C}_{29}$ regular steranes. However, the striking similarities and the presence of somewhat unusual components in pipe dope, as well as in the samples collected from the Lopra-1 well, prior to deepening, may sug- gest the presence of pipe dope contamination in the original borehole as well, the differences being accounted for by presumed differences between the pipe dopes used in the original and the deepened Lopra wells. Furthermore, the presence of a mid-Cretaceous or younger marly, anoxic marine source rock in the area, as implied by the geochemical data, seems geologically problematical. Carbonate or marly source rocks typically occur in lower latitude regions, i.e. areas within and close to the arid tropical belts (Tissot \& Welte 1984). It is estimated that during the Cretaceous, the Faroe Islands area was situated at $40-45^{\circ} \mathrm{N}$, and northward movement has prevailed since then ( $\mathrm{Ha}-$ bicht 1979; Scotese et al. 1988).

The biological marker characteristics of the extracts recovered from acid-digestion of a calcite-filled vug, and from its crushed tuff host-rock are totally dissimilar to the characteristics shown by all other samples from the well, including pipe dope. Principally, the distribution of triterpanes serves to distinguish these two samples from the remainder of the samples analysed. Hence, the following characteristic are noteworthy: lower proportions of tricyclic triterpanes, low norhopane to hopane ratio and the presence of 28,30-bisnorhopane. The signal-to-noise ratio is comparatively poor, but the overall biological marker characteristics show some similarities to oils generated from Upper Jurassic Kimmeridge Clay Formation sediments and their equivalents. This source system is known to be present in West of Shetlands basins (e.g. Scotchman et al. 1998) as well as in the North Sea basins, and can be prognosed for Faroese waters.

Glassley (2006, this volume) estimates that the maximum temperature reached at TD of the Lopra-1/1A reentry well was $200^{\circ} \mathrm{C}$. Provided that this estimate is correct, the temperature may be too high to allow preservation of higher molecular weight liquid hydrocarbons if maintained over prolonged periods of time. The maximum temperature actually recorded in the well was $98^{\circ} \mathrm{C}$, and assuming that the hydrocarbons found in RSWC \# 1 represent a thermogenic natural petroleum, this may have entered the tuff at a temperature lower than the maximum estimated by Glassley (2006, this volume), probably in connection with the formation of the calcite vug. Petroleum-bearing fluid inclusions have been observed in the same sample (Konnerup-Madsen 2006, this volume). Based on fluorescence colours (orange-yellow to green), an API gravity of 20-35 is estimated. No homogenisation temperature data have been recorded for the petroleumbearing inclusions, but data from non-hydrocarbon bearing inclusions fall in the range $101-186^{\circ} \mathrm{C}$, with the higher temperatures probably being caused by partial decrepitation. Hence, entrapment temperatures were probably con- 
siderably lower than the maximum temperature as estimated by Glassley (2006, this volume), and it is conceivable that the signal obtained represents indigenous crude oil. If so, this observation is very encouraging for future exploration in Faroese territorial areas.

\section{Conclusions}

All samples are to variable degrees contaminated by a number of adulterants of different origins. The adulterants include:

1. $n$-alkanes and other petroleum components originating from commercial diesel fuel;

2. pipe dope, an anti-seize compound used, for instance, when joining drilling rods;

3. squalene and cholesterol originating from naturally greasy fingers;

4. vitamin A and various esters used in cosmetics, including chap stick and hand lotion;

5. 2-ethylhexyl-phthalate, a widely used plasticiser for polymers/plastics.

A number of striking similarities in biological marker distributions between pipe dope and samples collected in the well prior to re-entry and deepening may suggest the presence of pipe dope contamination in the original well too, in addition to the presence of traces of petroleum hydrocarbons as shown by Laier et al. (1997).

Organic extracts recovered from dissolution of a calcite vug in RSWC \#1 (3543 m) and from its tuff host rock yield biological marker distributions different from all other samples collected in the Lopra-1 well. The distribution hints at generation from a marine anoxic shale source rock similar to the Kimmeridge Clay Formation and equivalents known from surrounding areas. It is conceivable that this organic extract represents an indigenous thermogenic petroleum, in particular since oil-bearing fluid inclusions have been observed in the same sample.

\section{Acknowledgements}

DANOP kindly supplied a sample of the pipe dope used during drilling of the well. Ditte Kiel-Dühring assisted in the preparation and analysis of the samples. Troels Laier and the reviewers Dr. R. Burwood and Dr. G. van Graas provided helpful comments and suggestions, which significantly improved the manuscript.

\section{References}

Boldreel, L.O. 2006: Wire-line log-based stratigraphy of flood basalts from the Lopra-1/1A well, Faroe Islands. Geological Survey of Denmark and Greenland Bulletin 9, 7-22 (this volume).

Glassley, W.E. 2006: Mineralogical and thermodynamic constraints on Palaeogene palaeotemperature conditions during low-grade metamorphism of basaltic lavas recovered from the Lopra-1/1A deep hole, Faroe Islands. Geological Survey of Denmark and Greenland Bulletin 9, 109-118 (this volume).

Habicht, J.K.A. 1979: Paleoclimate, paleomagnetism, and continental drift. AAPG Studies in Geology 9, 31 pp. + maps.

Heinesen, M.V., Larsen, A.R. \& Sørensen, K. 2006: Introduction. Geological Survey of Denmark and Greenland Bulletin 9, 5-6 (this volume).

Jacobsen, O.S. \& Laier, T. 1984: Analysis of gas and water samples from the Vestmanna-1 and Lopra-1 wells, Faeroe Islands. In: Berthelsen, O., Noe-Nygaard, A. \& Rasmussen, J. (eds): The deep drilling project 1980-91 in the Faeroe Islands. Annales Societatis Scientiarum Færoensis Supplementum IX, 149-155. Tórshavn: Føroya Frodskaparfelag.

Jørgensen, O. 1984: Zeolite zones in the basaltic lavas of the Faeroe Islands. In: Berthelsen, O., Noe-Nygaard, A. \& Rasmussen, J. (eds): The deep drilling project 1980-91 in the Faeroe Islands. Annales Societatis Scientiarum Færoensis Supplementum IX, 7191. Tórshavn: Føroya Frodskaparfelag.

Konnerup-Madsen, J. 2006: A reconnaissance study of fluid inclusions in fracture filling quartz and calcite from the Lopra-1/1A well, Faroe Islands. Geological Survey of Denmark and Greenland Bulletin 9, 119-122 (this volume).

Laier, T., Nytoft, H.P., Jørgensen, O. \& Isaksen, G.H. 1997: Hydrocarbon traces in the Tertiary basalts of the Faeroe Islands. Marine and Petroleum Geology 14, 257-266.

Peters, K.E. \& Moldowan, J.M. 1993: The biomarker guide, 363 pp. New Jersey: Prentice Hall.

Radke, M., Willsch, H. \& Welte, D.H. 1980: Preparative hydrocarbon group type determination by automated Medium Pressure Liquid Chromatography. Analytical Chemistry 52, 406-411.

Scotchman, I., Griffith, C.E., Holmes, A.J. \& Jones, D.M. 1998: The Jurassic petroleum system north and west of Britain: a geochemical oil-source correlation study. Organic Geochemistry 29, 671-700.

Scotese, C.R., Gahagan, L.M. \& Larson, R.L. 1988: Plate tectonic reconstruction of the Cretaceous and Cenozoic ocean basins. Tectonophysics 155, 27-48.

Tissot, B. \& Welte, D.H. 1984: Petroleum formation and occurrence, 2nd edition, 699 pp. Berlin: Springer Verlag.

Waagstein, R. 1988: Structure, composition and age of the Faeroe basalt plateau. In: Morton, A.C. \& Parson, L.M. (eds): Early Tertiary volcanism and the opening of the NE Atlantic. Geological Society Special Publication (London) 39, 225-238.

Waagstein, R., Hald, N., Jørgensen, O., Nielsen, P.H., Noe-Nygaard, A., Rasmussen, J. \& Schönharting, G. 1984: Deep drilling on the Faeroe Islands. Bulletin of the Geological Society of Denmark 32, 133-138. 